\title{
Potassium fertilization affects the distribution of fine roots but does not change ectomycorrhizal community structure
}

\author{
Lixia Wang ${ }^{1}$ - Klaus Katzensteiner ${ }^{1} \cdot$ Helmut Schume ${ }^{1}$ • Marcela Van Loo ${ }^{2}$. \\ Douglas L. Godbold ${ }^{1}$
}

Received: 30 November 2015 / Accepted: 26 April 2016/Published online: 20 May 2016

(C) INRA and Springer-Verlag France 2016

\begin{abstract}
- Key message $\mathrm{K}$ fertilization led to a significant increase in fine root biomass, fine root length, and root tip number in the mineral soil layer but does not affect the ecomycorrhizal community structure in the organic horizon.

- Context Potassium (K) deficiency is common in Picea abies in the European Alps. Fertilization with other nutrients often influences fine root biomass and ectomycorrhizas, but less is known about the effects of K-fertilization.

- Aims The aim of the investigation was to determine the effects of K-fertilization on stem growth and fine root biomass of Picea abies, as well as the influence on ectomycorrhizal community structure of the fine roots.
\end{abstract}

\section{Handling Editor: Ana Rincon}

Contribution of the co-authors Lixia Wang carried out the research, determined root biomass, identified ectomycorrhizas, and co-wrote the manuscript.

Klaus Katzensteiner designed and instigated the K-fertilization study, worked on drafts of the manuscript, and advised on statistics.

Helmut Schume carried out measurements of radial growth and commented on the manuscript.

Marcela van Loo was involved in molecular determination of ectomycorrhizas and revised the manuscript.

Douglas Godbold lead the research on root and mycorrhizas, supervised Lixia Wang, and co-wrote the manuscript.

Electronic supplementary material The online version of this article (doi:10.1007/s13595-016-0556-3) contains supplementary material, which is available to authorized users.

Lixia Wang

lixia.wang@boku.ac.at

1 Institute of Forest Ecology, Universität für Bodenkultur (BOKU), 1190 Vienna, Austria

2 Institute of Silviculture, Universität für Bodenkultur (BOKU), 1190 Vienna, Austria
- Methods Eight years after a single fertilization of Kdeficient Picea abies with $200 \mathrm{~kg} \mathrm{~K} \mathrm{ha}{ }^{-1}$, fine roots were collected from 7 control and $6 \mathrm{~K}$-fertilized plots. Fine root biomass and morphology were determined. The identification of ectomycorrhizal taxa was determined by morphotyping and by amplification of the internal transcribed spacer region of the nuclear ribosomal DNA.

- Results K-fertilization did not affect the amount of fine root biomass and ectomycorrhizal community structure in the $\mathrm{Oi}+$ $\mathrm{Oe}$ and $\mathrm{Oa}$ layers but led to a significant increase in fine root biomass, fine root length, and root tip number in the mineral soil layer.

- Conclusion An increase in growth due to K-fertilization leads to great exploration of the mineral soil by fine roots but does not affect the ectomycorrhizal community structure in the organic horizons.

Keywords Picea abies $\cdot$ Radial growth $\cdot$ Potassium . Diversity · Abundance

\section{Introduction}

Tree growth in alpine and boreal forest is often limited by deficiency of mineral nutrients especially nitrogen $(\mathrm{N})$ (Tamm 1991) and water (Bergh et al. 1999). Jonard et al. (2014) showed potassium $(\mathrm{K})$ deficiencies in $36 \%$ of spruce trees analyzed in the International Co-operative Programme, ICP Forest, and decreasing trends of the foliar K-status for this species. As a result of geological substrates low in K (Führer and Neuhuber 1998), and the remnant effects of acid deposition and biomass harvesting (Glatzel 1991), sub-optimal needle levels of K are common in montane forests in Austria. Due to the pivotal roles of many nutrients such as $\mathrm{N}$, phosphorus $(\mathrm{P})$, and $\mathrm{K}$ in photosynthesis, fertilization with these elements often results in an increase in 
photosynthesis rates (Linder and Troeng 1980). For example, in eucalyptus, K-fertilization increased photosynthesis (BattieLaclau et al. 2014) and increased aboveground biomass (Laclau et al. 2009; Epron et al 2011). In addition, $\mathrm{K}$ also has an important role in the movement of sucrose in and out of phloem vessels (Hermans et al. 2006); thus, K deficiency can strongly influence tree carbon (C) allocation (Epron et al 2011). In studies of Betula pendula seedlings, the root fraction of total seedling biomass decreased with increasing $\mathrm{K}$ limitation (Ericsson and Kähr 1993). Although fine roots represent a small proportion of total plant biomass (Vanninen and Mäkelä 1999), the morphology and the distribution of fine roots in the soil are very important factors for nutrient and water acquisition, which have impacts on growth (Nadelhoffer and Raich 1992). Fertilization of forest soils can result in changes in fine root biomass through direct improvement of soil chemical properties, such as after liming (Hahn and Marschner 1998). However, changes in fine root biomass can also be a consequence of greater aboveground growth or changes in allocation after fertilization (Kreutzer 1995; Helmisaari and Hallbäcken 1999). After $\mathrm{N}$-fertilization, fine root biomass of Picea abies was increased in upper soil layers (Persson and Ahlström 1990). Investigations of the effects of K-fertilization on the fine root growth of forest trees at a stand level are rare (Tripler et al. 2006). In an old growth tropical forest, Wurzburger and Wright (2015) showed a significant reduction of fine root biomass in the surface soil ( 0 $10 \mathrm{~cm}$ depth). The decrease in biomass was a consequence of reduced fine root tissue density and not a lower fine root length (Wurzburger and Wright 2015).

$>$ Mycorrhiza is a mutualistic symbiosis between plant roots and fungi, which plays a critical role in the uptake and transport of poorly mobile soil nutrients, such as $\mathrm{P}$ and $\mathrm{K}$ (Marschner and Dell 1994). Although K can be abundant in soils, due to strong mineral adsorption, $\mathrm{K}$ availability can be low. Ectomycorrhizas can enhance $\mathrm{K}$ uptake and storage in roots by increasing the size of vacuolar pools and through increasing $\mathrm{K}$ influx rates and decreasing K efflux rates (Rygiewicz and Bledsoe 1984). In natural ecosystems, the fine roots of most trees are colonized by a large number of ectomycorrhizal fungal species (Erland and Taylor 1999; Courty et al. 2008). Such investigations have shown that ectomycorrhizal communities in forests can be highly diverse, but these communities tend to be dominated by a few species and have a high number of rare species (Erland and Taylor 1999; Courty et al. 2008). The ectomycorrhizal community structure is influenced by tree species (Lang et al. 2011) and also by environmental factors such as nutrients (Jones et al. 2012). In a long term study of mixed (N, P, K, magnesium $(\mathrm{Mg})$, sulphur (S), and boron (B)) fertilizer application, fertilization tended to decrease species (Operational Taxonomic Units) richness of ectomycorrhizas associated with Pinus contorta (Hay et al. 2015). Nitrogen availability influences ectomycorrhizal species community composition in European Pinus sylvestris forests (Cox et al. 2010). Changes in ectomycorrhizal community structure are also common after addition of $\mathrm{N}$ containing fertilizer (Peter et al. 2001). Changes in community structure of ectomycorrhizas after $\mathrm{N}$-fertilization can be a result of increases in tree productivity but also direct effects of $\mathrm{N}$ on nitrophobe ectomycorrhizal species (Peter et al. 2001). Several factors that increase tree productivity have been shown to change community structure of ectomycorrhizas; these include elevated $\mathrm{CO}_{2}$ (Fransson et al. 2001; Godbold et al. 2015), defoliation (Pestana and Santolamazza-Carbone 2011), and stem harvesting (Jones et al. 2010). The change in ectomycorrhizal community structure through all of these factors is linked to changes in $\mathrm{C}$ allocation to roots (Godbold et al. 2015).

Studies of K-fertilization of forest trees are less common than studies with other nutrients (Wurzburger and Wright 2015; Ouimet and Moore 2015). Despite the negative effects of low $\mathrm{K}$ availability in montane forests, to the best of our knowledge, there are no published investigations of the effects of remedial K-fertilization on roots and ectomycorrhizas in European forests. In the work presented here, the influence of K-fertilization on fine root biomass and ectomycorrhizal community structure of Picea abies is investigated. The work tested the hypothesis that K-fertilization would lead to an increase in tree growth and subsequent increase in fine root biomass. Furthermore, we investigated whether changes in aboveground growth and fine root biomass lead to changes in ectomycorrhizal community structure.

\section{Materials and methods}

\subsection{Study site}

The research site is located at the Niederwechsel in the Southeast of Austria ( $\left.47^{\circ} 31^{\prime} 50^{\prime \prime} \mathrm{N}, 15^{\circ} 59^{\prime} 20^{\prime \prime} \mathrm{E}\right)$. The stocking of the stand (55 years old in 2005) was dominated by Norway spruce (Picea abies) with additional single stems of Larix decidua and P. sylvestris. The stocking density was around $1250 \mathrm{stems} \mathrm{ha}^{-1}$; the dominant tree height at the time of fertilizing (2005) was $16 \mathrm{~m}$. The stem diameters were primarily in the distribution classes between 13 and $20 \mathrm{~cm}$ (Online resource 1). The site is 18 to $20 \%$ inclined towards South to Southwest and is located between 1100 and $1200 \mathrm{~m}$ above sea level. The bedrock consists of Gneiss and Slate, from which a Skeletic Dystric Cambisol has developed. In terms of texture, the soil was classified as a sandy loam, while Moder constitutes the humus form (Zanella et al. 2011). The stone volume in the soil was estimated to be in total between 37 and $60 \%$. The volume of stones $<63 \mathrm{~mm}$ was $12 \%$ in the A horizon and $35 \%$ in the B horizon. The volume of stones $>63 \mathrm{~mm}$ was $25 \%$ in both horizons. 
Few stones were present in the organic horizons. The site has an oligotrophic character and is moderately dry. At the time of sampling in 2013, the $\mathrm{pH}$ of the soil was between 4.3 and 4.4 (water) and the water content of the humus layer ca. 56-58\%. There were no significant differences in soil moisture or $\mathrm{pH}$ between plots or treatments.

Analysis in 2004 showed that Picea abies trees at the site had a strong potassium deficiency, with needle values of 2.5 to $3 \mathrm{mg} \mathrm{g}^{-1}$ needle dry mass (Katzensteiner et al. 2008). Mellert and Göttlein (2012) set the lower limit of the normal range at $5.2 \mathrm{mg} \mathrm{g}^{-1}$ and the lower limit of latent deficiency at $3.5 \mathrm{mg} \mathrm{g}^{-1}$ (Mellert and Göttlein 2012). There were no significant differences in the $\mathrm{K}$ content between the $\mathrm{K}$-fertilized plots and the control plots at the beginning of the experiment. Prior to the experiment, the cation exchange capacity was around $15 \mathrm{mmol}_{\mathrm{c}} 100 \mathrm{~g}^{-1}$ in the topsoil (0-10 $\mathrm{cm}$ depth), decreasing to $<2 \mathrm{mmol}_{\mathrm{c}} 100 \mathrm{~g}^{-1}$ in the subsoil. The base saturation varied between $<10$ and $20 \%$.

\subsection{Experimental design}

In 2004, 18 plots of ca. $400 \mathrm{~m}^{2}$ were established, of which 9 were fertilized in June 2005 with potassium sulphate $(\mathrm{K}+\mathrm{S}$, Kali GmbH, Kassel). The product used contained $40 \%$ watersoluble $\mathrm{K}$ and was distributed by hand to the equivalent of $500 \mathrm{~kg} \mathrm{ha}^{-1}$, giving a $\mathrm{K}$ addition of ca. $200 \mathrm{~kg} \mathrm{ha}^{-1}$. All research plots were established in the same stand, which was homogeneous with respect to stand composition and site conditions. The plots were assigned randomly (Online resource 2 ). In the work described here, samples were taken from 7 control plots and $6 \mathrm{~K}$-fertilized plots.

\subsection{Determination of basal area and radial growth}

Stand basal area increment was assessed by two complete inventories of diameters in breast height (DBH) in spring 2005 and autumn 2013 using a Pi-tape. Therefore, the given basal area increments reflect the increments of 9 growing seasons. Additionally, the diameter increment in breast height of one tree per plot was measured in intervals of approximately 1 week using dendrometer tapes. For a very high resolution in time, three trees per treatment were equipped with automatically registering dendrometers (Environmental Measuring Systems, Brno, Czech Republic). Values were recorded in 15-min intervals.

\subsection{Root sampling and analysis}

Five soil samples were taken from each of the seven control plots and the $6 \mathrm{~K}$-fertilized plots with a stainless steel corer ( $7 \mathrm{~cm}$ diameter) to a maximum depth of $40 \mathrm{~cm}$ in
September 2013. Sampling of soil cores and roots was restricted to the plot centers (inner squares of 10 by $10 \mathrm{~m}$ ) in order to avoid a bias by potential fertilizer transfer via lateral water flux. The soil cores were transported on ice back to the laboratory where they were stored at $4{ }^{\circ} \mathrm{C}$ for later examination. All soil cores were analyzed within 4 weeks. For analysis of fine roots and ectomycorrhizas, the organic layer of the soil cores were divided into an $\mathrm{Oi}+\mathrm{Oe}$ layer composed of non or poorly decomposed litter, and an Oa layer in an advanced stage of decomposition (Zanella et al. 2011), as well as a mineral soil layer of $15 \mathrm{~cm}$ length. Taking a $15 \mathrm{~cm}$ length of the mineral soil normalized the maximum sampling depth to ca. $30 \mathrm{~cm}$. The thickness of each horizon $(\mathrm{Oi}+\mathrm{Oe}, \mathrm{Oa}$, and mineral soil) was determined and used to calculate fine root biomass per soil volume. The thickness of $\mathrm{Oi}+$ Oe was $6.6 \pm 0.4 \mathrm{~cm}$ in control plots and was $6.8 \pm 0.4 \mathrm{~cm}$ in K-fertilized plots; the thickness of Oa was $8.2 \pm 0.9 \mathrm{~cm}$ in the control plots and was $7.5 \pm 0.8 \mathrm{~cm}$ in K-fertilized plots. From each horizon, roots were removed by hand sorting and categorized as dead or alive on the basis of color and tensile strength. Live roots were categorized into fine roots $(<2 \mathrm{~mm}$ diameter) and coarse roots $(>2 \mathrm{~mm}$ diameter). From three soil cores per plot, from the fine roots removed from each $\mathrm{Oi}+\mathrm{Oe}$ and $\mathrm{Oa}$ horizon, a subsample was taken for ectomycorrhizal analysis. For determination of ectomycorrhizas in total, 22 soil cores (one extra core was analyzed) from control plots and 19 soil cores (one extra core was analyzed) from K-fertilized plots were analyzed. The root segments removed in the subsamples had approximately 150-300 root tips. The subsamples were then washed carefully, placed into petri-dishes filled with clean tap water, and stored at $4{ }^{\circ} \mathrm{C}$ (analyzed within three weeks). All clearly definable ectomycorrhizal root tips from each sample (22 soil cores $\times$ two soil layers $=44$ samples for control plots; 19 soil cores $\times$ two soil layers $=38$ samples for K-fertilized plots, respectively) were sorted into morphotypes based on the method described by Agerer (1997), using a ZEISS (Stemi 2000-CS) dissecting microscope which was connected with an AxioCam ERc5s camera. The method of Agerer (1997) is based on morphological characteristics, including branching structure, tip shape and dimensions, mantle color and texture, and emanating hyphae and rhizomorphs. This method allows identification of ectomycorrhizas to genus or species levels and is referred to as morphotypes in the following text. The final identification to genus or species level (where possible) was carried out by sequencing of DNA (see below) and after identification are referred to as taxa (Read et al. 2004). The total number of root tips colonized by each of the morphotype was counted under the dissecting microscope. 
Between 1 and 10, ectomycorrhizal root tips of each morphotype were placed into micro-centrifuge tubes. The number of root tips varied from one to ten depending on the abundance of the morphotype. The samples were then stored at $-20{ }^{\circ} \mathrm{C}$ until DNA extraction. The remainder of the root subsample was then scanned using the WinRHIZO program to determine the total number of fine root tips, as well as the length of the fine roots for each sample. The fine root subsamples and the remaining total fine root mass were subsequently oven dried $\left(65^{\circ} \mathrm{C}\right)$ and weighed. From each soil core and horizon, all root samples, both the total mass samples and the subsamples, were dried and weighed separately, and the values were used to calculate a mean for each plot.

Fine root biomass per $\mathrm{m}^{2}$ was calculated using the surface area of the core and scaled to $\mathrm{m}^{2}$. The values of fine root biomass in the mineral soil were corrected for the volume content of stones $>63 \mathrm{~mm}$. Biomass per cubic decimeter was determined by scaling the volume of the soil horizon sampled to $1 \mathrm{dm}^{3}$. The measurements of length, root tips, and fine root dry weight were used to calculate specific root tip number (tips $\mathrm{g}^{-1} \mathrm{Dwt}$ ) and specific root length (m length $\mathrm{g}^{-1} \mathrm{Dwt}$ ).

\subsection{DNA extraction and PCR amplification}

The 1.5-ml micro-centrifuge tubes containing the ectomycorrhizal root tips were placed in liquid nitrogen for 5-10 min, and the tips were ground with a sterilized glass bar. DNA from the crushed ectomycorrhizal root tips was extracted by using DNeasy Plant Mini kits (QIAGEN), and the extracted DNA was stored at $-20{ }^{\circ} \mathrm{C}$ until the PCR reactions were run. For the PCR reactions, $1 \mu \mathrm{l}$ DNA template was mixed with $12.5 \mu \mathrm{l}$ MyTaq mix (BIOLINE), $0.5 \mu \mathrm{l}$ ITS1F $(20 \mu \mathrm{M})$ primer (CTTGGTCATTTAGAGGAAGTAA forward), $0.5 \mu 1$ ITS4 $(20 \mu \mathrm{M})$ primer (TCCTCCGCTTATTGATATGC reverse), and diluted with $10.5 \mu \mathrm{l}$ distilled deionized $\mathrm{H}_{2} \mathrm{O}$. For the PCR, the Thermocyler (TProfessional Basic) cycling parameters were an initial denaturation at $95{ }^{\circ} \mathrm{C}$ for $1 \mathrm{~min}$, a second denaturation at $94{ }^{\circ} \mathrm{C}$ for $30 \mathrm{~s}$, annealing at $50{ }^{\circ} \mathrm{C}$ for $40 \mathrm{~s}$, and extension at $72{ }^{\circ} \mathrm{C}$ for $30 \mathrm{~s}$, followed by a final auto-extension step at $72{ }^{\circ} \mathrm{C}$ for $4.5 \mathrm{~min}$. The step from the second denaturation to extension was run for 35 cycles. To check the success of the PCR amplification, electrophoresis was carried out using $1 \%$ regular agarose gel stained with SERVA DNA Stain G in a $1 \%$ Tris-EDTA buffer solution. The gel was then visualized under UV light. If a clear single band was visible on the gel, the PCR products were sent for sequencing. Sequencing was done by Macrogen Inc., Seoul, Korea.
Sequencing reactions were performed in a MJ Research PTC-225 Peltier Thermal Cycler using a ABI PRISM ${ }^{\circledR}$ BigDyeTM Terminator Cycle Sequencing Kits with AmpliTaq ${ }^{\circledR}$ DNA polymerase (FS enzyme) (Applied Biosystems), following the protocols supplied by the manufacturer. Single-pass sequencing was performed on each template using an ITS4 primer. The fluorescent-labeled fragments were purified from the unincorporated terminators using the BigDye ${ }^{\circledR}$ XTerminator ${ }^{\mathrm{TM}}$ purification protocol. The samples were resuspended in distilled water and subjected to electrophoresis in an ABI PRISM ${ }^{\circledR}$ 3730XL sequencer (Applied Biosystems). The sequences obtained were manually checked and edited using Finch TV_1_4_0. Query sequences were compared with sequences on the UNITE and NBCI databases to identify the species of ectomycorrhiza; all but one of the sequences had a similarity of over $97 \%$ (Online resource 3). The sequences were deposited in GenBank with Accession No. KU861471-KU861502. Four morphotypes could not be identified using the DNA analysis and were labelled as unknown.

\subsection{Statistical analyses}

Relative frequency was calculated as the absolute frequency of individual taxa divided by the sum of absolute frequencies for all taxa (equation 1). Relative abundance was calculated as the ectomycorrhizal root tips of individual taxa divided by the total ectomycorrhizal root tips for all taxa (equation 2). Importance values for individual ectomycorrhizal fungal taxa were calculated by summing their relative abundance and their relative frequency (equation 3) (Douglas et al. 2005). For the parameters determined, the significance of the difference between control and K-fertilized plots, and also the difference between the soil layers, were tested using two-way analysis of variance (ANOVA). The parameters determined were fine root biomass ( $\mathrm{g}$ fine root $\mathrm{m}^{-2}$ soil surface area), fine root density (g fine root per cubic decimeter soil volume), fine root tips (shown as thousands of fine root tips $\mathrm{m}^{-2}$ soil surface area), fine root length ( $\mathrm{m}$ fine root length $\mathrm{m}^{-2}$ soil surface area), specific root length, specific root tip number, and the Student-Newman-Keuls test was used for post hoc multiple comparison in SPSS. Difference in Shannon index, ectomycorrhizal root tips relative abundance and importance value between control and Kfertilized plots, and the relative frequency, ectomycorrhizal root tips abundance between different soil layers, were tested using the $t$ test. Estimation of the total number of expected taxa was made with the program Estimates using the Chao estimator of taxa richness .

Equations: 
Relative Frequency $=\mathrm{fi} / \Sigma \mathrm{f}$ (frequency of a given taxa (fi) as a proportion of the sum of the frequencies for all taxa) $(1)$

Relative Abundance $=\mathrm{ni} / \Sigma \mathrm{ni}(\mathrm{ni}$ is the number of individuals of a given taxa counted $)$

Importance Value $=$ Relative Abundance + Relative Frequency

\section{Results}

In 2005, the basal area of spruce was not significantly different between the control and K-fertilized plots (Table 1). Spruce represents $82 \%$ of the total stand basal area (Online resource 1). By 2013, the basal area had increased by $6.5 \mathrm{~m} \mathrm{ha}^{-1}$ in the control plots and by $8.2 \mathrm{~m}^{2} \mathrm{ha}^{-1}$ in the K-fertilized plots. The basal area increment was significantly different between the control and the $\mathrm{K}$-fertilized plots $(P=0.006)$.

\subsection{Fine root biomass}

For the whole soil profile, the total fine root biomass was 670 $\pm 71 \mathrm{~g} \mathrm{~m}^{-2}$ in the control plots and $790 \pm 66 \mathrm{~g} \mathrm{~m}^{-2}$ in the $\mathrm{K}-$ fertilized plots and was not significantly different. Similarly, there was no significant difference between control and Kfertilized plots in the $\mathrm{Oi}+\mathrm{Oe}$ or Oa layers for the fine root biomass determined as $\mathrm{g} \mathrm{m}^{-2}$ (Fig. 1a) or $\mathrm{g} \mathrm{dm}^{-3}$ (Fig. 1b). In the mineral soil, the fine root biomass (Fig. 1a, b) was almost twice as high in K-fertilized plots compared to the control plots, and significant differences were shown. The number of root tips (root tips $\mathrm{m}^{-2}$ ) was higher in the $\mathrm{Oi}+\mathrm{Oe}$ layer compared to the other two layers (Fig. 1c), and the difference was significant. In the mineral soil, a significantly higher number of fine root tips were found in the Kfertilized plots. Fine root length did not differ between the treatments in the $\mathrm{Oi}+\mathrm{Oe}$ and Oa layers but was significantly higher in the mineral soil of the K-fertilized plots (Fig. 1d).

\subsection{The comparison of fine root characteristics between two sites}

The patterns shown in fine root length and the number of root tips in the different soils layers and treatments are reflected in the specific root length and specific root tip number (Table 2). The specific root tip number (root tips $\mathrm{g}^{-1} \mathrm{dwt}$ ) was highest in the $\mathrm{Oi}+$ Oe layer compared to the other two layers (Table 2). There were no significant differences between the treatments in the $\mathrm{Oi}+\mathrm{Oe}$ and $\mathrm{Oa}$ layers, but in the mineral layer (0$15 \mathrm{~cm}$ ), the specific root tip number was significantly higher in the K-fertilized plots compared to the control plots $(P=0.006)$. Similarly, the specific root length was also highest in the $\mathrm{Oi}+$ Oe layer, and again in the mineral layer, there was a significant difference between the control and K-fertilized plots.

\subsection{Frequency, abundance, and diversity patterns of identified ectomycorrhizal taxa}

In the $\mathrm{Oi}+\mathrm{Oe}$ and $\mathrm{Oa}$ soil layers, a total of 22 ectomycorrhizal fungal taxa were determined. On the control plots 15 taxa and on the K-fertilized plots, 17 ectomycorrhizal fungal taxa were determined (Table 3). These were detected after examining 2094 and 1975 root tips from the control and K-fertilized plots, respectively (Table 3). Comparison of the total number of tips and the ectomycorrhizal tips (Table 3 ) shows that a large percentage of the tips did not have definable
Table 1 Basal area of the Picea abies plots in 2005 before fertilization with $500 \mathrm{~kg} \mathrm{ha}^{-1}$ $\mathrm{K}_{2} \mathrm{SO}_{4}$ and in 2013 at sampling. The basal area increment, total root biomass, and the ratio of fine root biomass to basal area of the control and the K-fertilized plots are also shown

\begin{tabular}{|c|c|c|c|c|}
\hline & \multicolumn{2}{|l|}{ Control } & \multicolumn{2}{|l|}{ K-fertilized } \\
\hline & 2005 & 2013 & 2005 & 2013 \\
\hline Basal area increment in percent & & $24.0 \pm 1.4 \mathrm{a}$ & & $28.8 \pm 1.1 b$ \\
\hline Total root biomass $\left(\mathrm{g} \mathrm{m}^{-2}\right)$ & & $670 \pm 71 \mathrm{a}$ & & $790 \pm 66 a$ \\
\hline Basal area in $\left(\mathrm{m}^{2} \mathrm{ha}^{-1}\right)$ & $27.2 \pm 3.4 \mathrm{a}$ & $33.7 \pm 4.2 \mathrm{a}$ & $28.4 \pm 3.1 \mathrm{a}$ & $36.6 \pm 4.2 b$ \\
\hline $\begin{array}{l}\text { Total root biomass/basal area } \\
\text { (g fine root } \mathrm{m}^{-2} \text { basal area) }\end{array}$ & & $20.1 \pm 2 \mathrm{a}$ & & $21.7 \pm 1.7 \mathrm{a}$ \\
\hline
\end{tabular}

Mean \pm SE. The $t$ test was used to determine the significance of difference between control and K-fertilized plots. Within a year, between control and K-fertilized plots, data points followed by different letters are significantly different $(P \leq 0.05)$ 
Fig. 1 a Fine root biomass ( $\mathrm{g}$ fine root $\mathrm{m}^{-2}$ soil surface area), b fine root density ( $\mathrm{g}$ fine root $\mathrm{dm}^{-3}$ soil volume), $\mathbf{c}$ fine root tips (1000 of fine root tips $\mathrm{m}^{-2}$ soil surface area), and $\mathbf{d}$ total fine root length ( $\mathrm{m}$ fine root length $\mathrm{m}^{-2}$ soil surface area) in different soil layers of control and $\mathrm{K}$-fertilized (500 kg ha ${ }^{-1} \mathrm{~K}_{2} \mathrm{SO}_{4}$ ) plots of Picea abies. Bars show means \pm SE. Bars with different lower case letters indicate significant differences between different soil layers in the same treatment $(P \leq 0.05)$. Asterisks indicate significant differences between control and K-fertilized plots for same soil layer $(P \leq 0.05)$
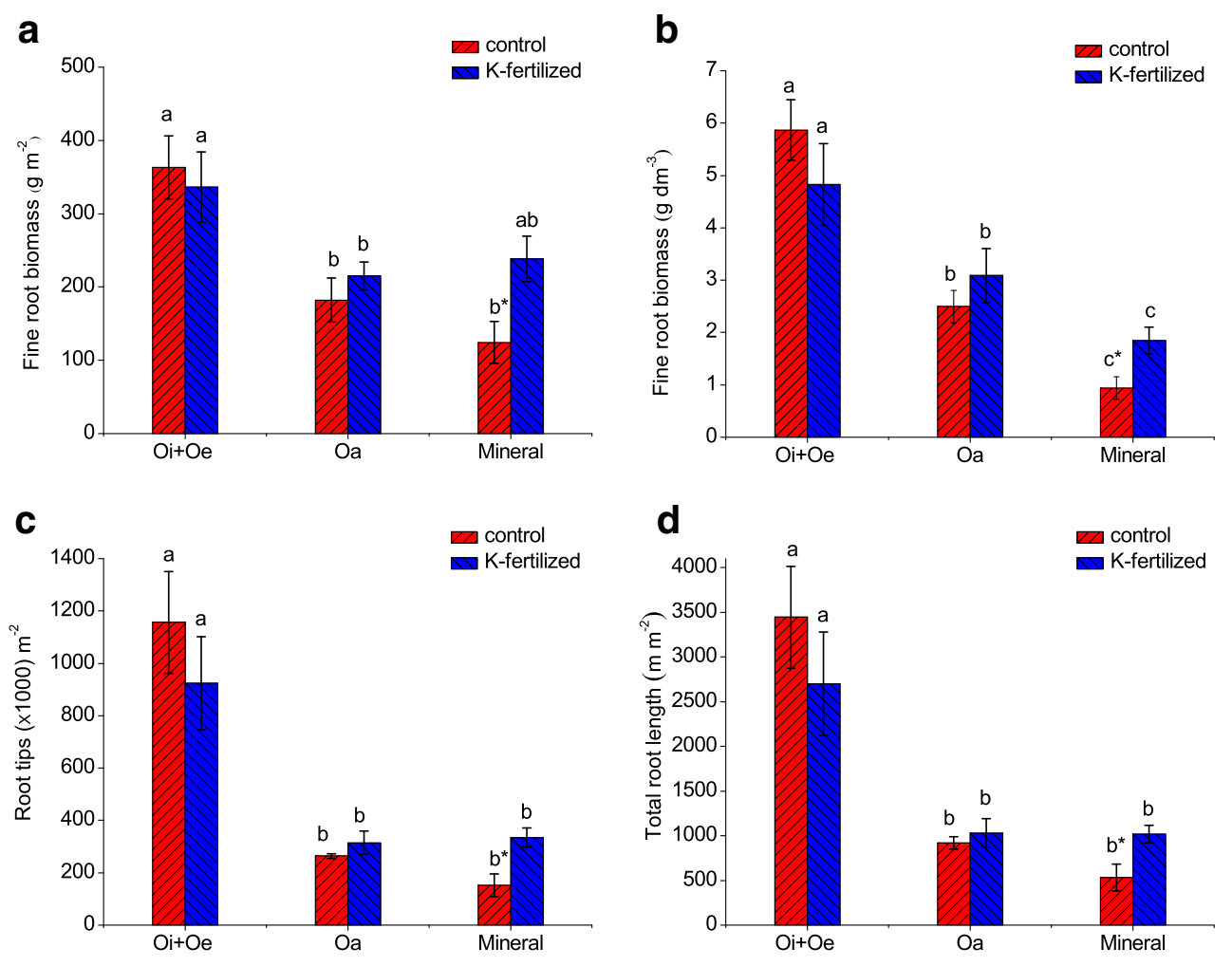

Soil layer

ectomycorrhizas. Using the program Estimates, the estimated total richness of taxa for the control and $\mathrm{K}$-fertilized was 23 and 26 taxa, respectively (Online resource 4, Table 3). Hence, the observed number of ectomycorrhizal taxa was $65 \%$ of the estimated richness in the control plots and $66 \%$ in the Kfertilized plots. The mean number of ectomycorrhizal taxa detected in each sample was ca. 2 and did not differ between control and K-fertilized plots (Table 3).

Ten taxa were detected that were shared between control and K-fertilized plots (Table 4). Lactarius rufus was the dominant taxa (Table 4 ) in both treatments comprising 43 or $32 \%$ of all ectomycorrhizal root tips in control and K-fertilized plots, respectively, but no significant difference was observed in relative abundance between the two sites $(P=0.401)$. However, numerically, L. rufus occurred in a greater number of samples and had a higher abundance value in the control plots. Cenococcum geophilum, Meliniomyces variabilis, and Tylospora fibrillosa were the other three most common taxa (Table 4). These taxa were similar between plots, both in the number of samples in which they were found, and in their relative abundance value (Table 4). Figure 2 shows that the two sites have a similar pattern when the importance values are ranked. For the three most important taxa, L. rufus, T. fibrillosa, and C. geophilum, no significant differences were found between control and K-fertilized plots $(P=0.426$, $P=0.922, P=0.279)$, respectively. Table 4 shows that C. geophilum comprised just over $7 \%$ of the total ectomycorrhizal root tips in control plots and nearly $10 \%$ of total ectomycorrhizal root tips in K-fertilized plots. M. variabilis comprised $3.9 \%$ of the total ectomycorrhizal root tips in control plots and $3.6 \%$ of the total ectomycorrhizal root tips in K-fertilized plots (Table 4). L. rufus and
Table 2 Specific root tip number and specific root length of the roots of Picea abies from different soil layers of control and $\mathrm{K}$ fertilized $\left(500 \mathrm{~kg} \mathrm{ha}^{-1} \mathrm{~K}_{2} \mathrm{SO}_{4}\right)$ plots

\begin{tabular}{|c|c|c|c|c|}
\hline & \multicolumn{2}{|c|}{ Specific root tip number (root tips $\mathrm{g}^{-1}$ root) } & \multicolumn{2}{|c|}{ Specific root length ( $\mathrm{m} \mathrm{g}^{-1}$ root) } \\
\hline & Control & K-fertilized & Control & K-fertilized \\
\hline $\mathrm{Oi}+\mathrm{Oe}$ & $3099 \pm 177 \mathrm{a}$ & $2657 \pm 260 \mathrm{a}$ & $9.30 \pm 0.58 \mathrm{a}$ & $7.72 \pm 0.89 \mathrm{a}$ \\
\hline $\mathrm{Oa}$ & $1559 \pm 33 b$ & $1474 \pm 25 b$ & $5.27 \pm 0.42 b$ & $4.93 \pm 0.56 b$ \\
\hline Mineral & $826 \pm 61 c^{*}$ & $1647 \pm 17 b$ & $2.74 \pm 0.61 \mathrm{c}^{*}$ & $4.88 \pm 0.54 \mathrm{~b}$ \\
\hline
\end{tabular}

Mean \pm SE. Data points with different lower case letters indicate significant differences between different soil layers in the same treatment $(P \leq 0.05)$. Asterisks indicate significant differences between control and K-fertilized plots for same soil layer $(P \leq 0.05)$ 
Table 3 The number of root tips and total number of ectomycorrhizal root tips examined per treatment and the detected and estimated number of taxa in the $\mathrm{Oi}+\mathrm{Oe}$ and $\mathrm{Oa}$ soil layers of control and $\mathrm{K}$-fertilized $\left(500 \mathrm{~kg} \mathrm{ha}^{-1} \mathrm{~K}_{2} \mathrm{SO}_{4}\right)$ plots

\begin{tabular}{lll}
\hline Characteristics & Control & K-fertilized \\
\hline Total taxa detected & 15 & 17 \\
Mean taxa per sample & $2.0 \pm 0.2 \mathrm{a}$ & $1.9 \pm 0.2 \mathrm{a}$ \\
Estimated richness & 23 & 26 \\
Shannon index & $1.8 \pm 0.1 \mathrm{a}$ & $1.9 \pm 0.1 \mathrm{a}$ \\
Total root tips & 9944 & 9175 \\
Total ectomycorrhizal root tips & 2094 & 1975 \\
\hline
\end{tabular}

Shown is the Mean \pm SE. As indicated by the same letters, the values of mean taxa per sample and Shannon index were not significantly different between control and $\mathrm{K}$-fertilized $(P \leq 0.05)$

C. geophilum together comprised almost half of the ectomycorrhizal fungal root tips at both sites (Table 4).

For the most common taxa at the site, there were no significant differences in tip abundance or importance value between the control and K-fertilized plots (Table 4, Fig. 2). The main difference between the ectomycorrhizal community structures of the treatments was in the rare taxa. In both treatments, a number of rare taxa occurred only in 1 or 2 samples (Table 4). Of the 9 or 10 taxa that occurred in 1 or 2 samples in the control and K-fertilized treatment, respectively (Table 4), and had a low importance rank (Fig. 2), four taxa occurred in both treatments, Piloderma sphaerosporum, Cortinarius delibutus, Cortinarius neofurvolaesus, and Lactarius lilacinus. Thus, of the rare taxa that were not common to both treatments, four occurred in the control and six in the Kfertilized plots. Of these, two morphotypes could not be identified in both treatments. The Shannon diversity index, calculated from values from the Estimates program, was also not significantly different between control and K-fertilized plots $(P=0.461)$.

\subsection{Vertical distribution of 10 shared ectomycorrhizal fungal taxa}

The distribution of the 10 shared ectomycorrhizal taxa in the $\mathrm{Oi}+\mathrm{Oe}$ and $\mathrm{Oa}$ layer is presented in Fig. 3. Among these 10 shared ectomycorrhizal fungal taxa, L. rufus, C. neofurvolaesus, T. fibrillosa, and C. delibutus appeared
Table 4 The 22 ectomycorrhizal fungal taxa detected on the roots of Picea abies from control and $\mathrm{K}$-fertilized $\left(500 \mathrm{~kg} \mathrm{ha}^{-1} \mathrm{~K}_{2} \mathrm{SO}_{4}\right)$ plots

\begin{tabular}{|c|c|c|c|c|c|}
\hline \multicolumn{3}{|l|}{ Control } & \multicolumn{3}{|l|}{ K-fertilized } \\
\hline Fungal taxa & Occurrence & Abundance & Fungal taxa & Occurrence & Abundance \\
\hline Lactarius rufus & 22 & 0.428 & Lactarius rufus & 17 & 0.321 \\
\hline $\begin{array}{r}\text { Cenococcum } \\
\text { geophilum }\end{array}$ & 11 & 0.07 & $\begin{array}{r}\text { Cenococcum } \\
\text { geophilum }\end{array}$ & 12 & 0.098 \\
\hline Tylospora fibrillosa & 8 & 0.122 & $\begin{array}{l}\text { Meliniomyces } \\
\text { variabilis }\end{array}$ & 7 & 0.036 \\
\hline $\begin{array}{l}\text { Meliniomyces } \\
\text { variabilis }\end{array}$ & 7 & 0.039 & Tylospora fibrillosa & 6 & 0.094 \\
\hline Russula ochroleuca & 7 & 0.025 & Tylospora asterophora & 4 & 0.063 \\
\hline Paxillus involutus & 4 & 0.038 & Cortinarius subtortus & 3 & 0.035 \\
\hline Cortinarius delibutus & 2 & 0.121 & Russula ochroleuca & 3 & 0.003 \\
\hline Tylospora asterophora & 2 & 0.031 & $\begin{array}{l}\text { Cortinarius } \\
\quad \text { neofurvolaesus }\end{array}$ & 2 & 0.147 \\
\hline Unknown 14 & 2 & 0.046 & $\begin{array}{l}\text { Piloderma } \\
\quad \text { sphaerosporum }\end{array}$ & 2 & 0.037 \\
\hline Boletus edulis & 2 & 0.021 & Cortinarius delibutus & 2 & 0.104 \\
\hline Lactarius lilacinus & 2 & 0.014 & $\begin{array}{l}\text { Cortinarius } \\
\quad \text { glandicolor }\end{array}$ & 1 & 0.025 \\
\hline $\begin{array}{l}\text { Cortinarius } \\
\quad \text { neofurvolaesus }\end{array}$ & 1 & 0.017 & Unknown 22 & 1 & 0.019 \\
\hline Piloderma olivaceum & 1 & 0.022 & Clavulina spp. & 1 & 0.004 \\
\hline $\begin{array}{l}\text { Piloderma } \\
\quad \text { sphaerosporum }\end{array}$ & 1 & 0.004 & Rhizopogon salebrosus & 1 & 0.002 \\
\hline \multirow[t]{3}{*}{ Unknown 11} & 1 & 0.003 & Unknown 21 & 1 & 0.007 \\
\hline & & & $\begin{array}{l}\text { Amanita } \\
\quad \text { submembranacea }\end{array}$ & 1 & 0.003 \\
\hline & & & Lactarius lilacinus & 1 & 0.001 \\
\hline
\end{tabular}

Taxa common to both treatments are shown in bold typeface. Shown are the number of samples in which each taxa occurred out of a total of 44 samples (control) and 38 samples (K-fertilized), as well as the relative root tip abundance of each taxa calculated as a fraction of the total number of ectomycorrhizal root tips per treatment 
Fig. 2 a, b Ranked distributions of different ectomycorrhizal taxa according to importance values based on the sum of relative ectomycorrhizal root tip abundance and relative sample frequencies of ectomycorrhizal taxa on the roots of Picea abies taken from a control plots and $\mathbf{b}$ $\mathrm{K}$-fertilized $\left(500 \mathrm{~kg} \mathrm{ha}^{-1} \mathrm{~K}_{2} \mathrm{SO}_{4}\right)$ plots. Numbers at the end of each bar correspond to sample frequency for each taxa and the percent of total ectomycorrhizal root tips (see legend to Table 4)

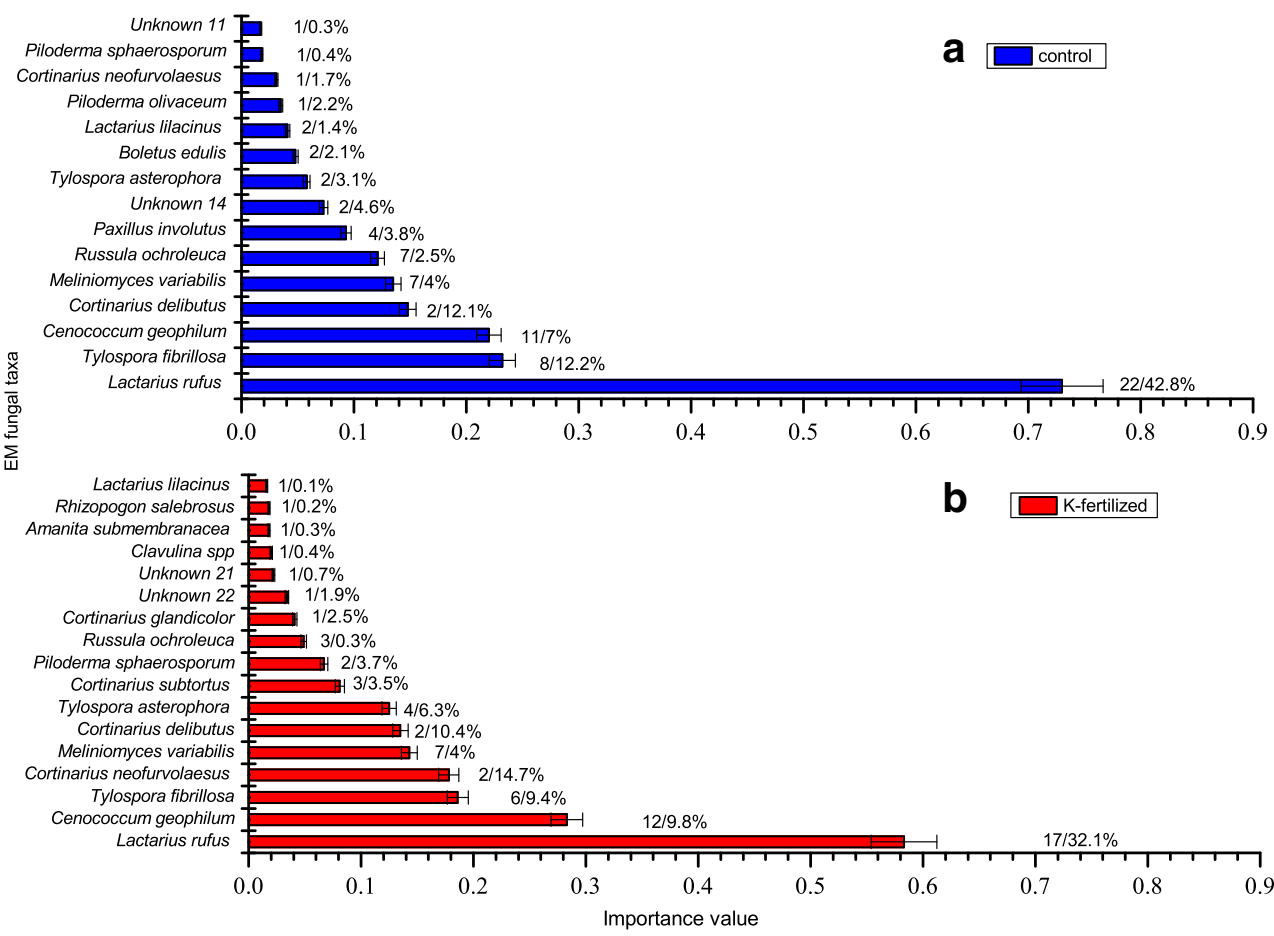

more often and abundant in the $\mathrm{Oi}+\mathrm{Oe}$ layer than the $\mathrm{Oa}$ layer. Significant differences were detected in the absolute abundance of L. rufus $(P=0.001)$ and in T. fibrillosa $(P=0.048)$ in the $\mathrm{Oi}+$ Oe layer.

\section{Discussion}

\subsection{Comparison of fine root distribution between treated and control plots}

Over the 8-year treatment period, a single K-fertilization led to a sustained increase in basal area increment of ca. $26 \%$. Before fertilization, the stand at Niederwechsel had low levels of $\mathrm{K}$ in needles and also yellowish short needles (Katzensteiner et al. 2008). In a young Abies balsamea stand with symptoms of chlorosis, K-fertilization led to an increase in radial growth for over 11 years (Ouimet and Moore 2015). The $26 \%$ increase in radial growth shown at Niederwechsel after $\mathrm{K}$-fertilization is of a similar value to that induced by elevated $\mathrm{CO}_{2}$. An average increase in growth of $23 \%$ was shown in free air carbon dioxide enrichment studies (Norby et al. 2005; Smith et al. 2013). In N-fertilization experiments in Picea abies stands in Sweden, the average increase in radial growth was ca. $30 \%$ after a single addition of $150 \mathrm{~kg} \mathrm{~N}^{-1}$ (Nohrstedt 2001). In Eucalyptus, fertilization with K doubled $\mathrm{CO}_{2}$ assimilation rates (Battie-Laclau et al. 2014). In an adjacent experiment, the $\mathrm{K}$ addition lead to an increase in the amount of gross primary production allocated to stem wood production (Epron et al. 2011). The increase growth under elevated $\mathrm{CO}_{2}$ was also a direct consequence of increased rates of photosynthesis. Similarly, N-fertilization resulted in higher levels of needle chlorophyll and higher rates of photosynthesis per unit area of needles in Picea abies (Linder and Troeng 1980).

Addition of nutrients can result in greater fine root growth through the direct effects of changes in soil chemistry and nutrient availability (Hahn and Marschner 1998), but also via indirect effects through greater aboveground productivity, and thus greater $\mathrm{C}$ availability to fine roots (Norby et al. 2010). The greater productivity can be achieved as discussed above by fertilization with $\mathrm{K}, \mathrm{N}$, or $\mathrm{CO}_{2}$; however, the effects of elevated $\mathrm{CO}_{2}$ are only via aboveground driven changes in productivity. Thus, comparison between $\mathrm{K}$ - and $\mathrm{N}$ fertilization and elevated $\mathrm{CO}_{2}$ may be a useful tool to distinguish the direct and indirect effects of fertilization on fine root biomass. In an old growth tropical forest (Wurzburger and Wright 2015), K-fertilization resulted in a significant reduction in fine root biomass of the surface soil (0-10 cm depth). This is in contrast to the results of our study in which Kfertilization had no effect on roots in the upper organic soil layers but significantly increased fine root biomass in the mineral soil. As in 2006, 1 year after fertilization, fine root biomass had not changed (Katzensteiner et al. 2008); it is unlikely that these changes are due to the direct effects of changes in soil chemistry. A similar increase in fine root biomass in the mineral soil layer was shown after $\mathrm{MgSO}_{4}$ fertilization of $\mathrm{Mg}$ deficient Picea abies (Raspe 1997). In comparison, fertilization with dolomitic lime resulted in an increase in fine root biomass only in the organic soil horizons (Raspe 1997). 
Fig. 3 Comparison of the importance value of shared ectomycorrhizal taxa on roots of Picea abies taken from the $\mathrm{Oi}+$ $\mathrm{Oe}$ and $\mathrm{Oa}$ layers in control and K-fertilized (500 kg ha $\left.{ }^{-1} \mathrm{~K}_{2} \mathrm{SO}_{4}\right)$ plots. Mean \pm SE. The importance value was calculated from the sum of the relative ectomycorrhizal root tip abundance and relative sample frequencies

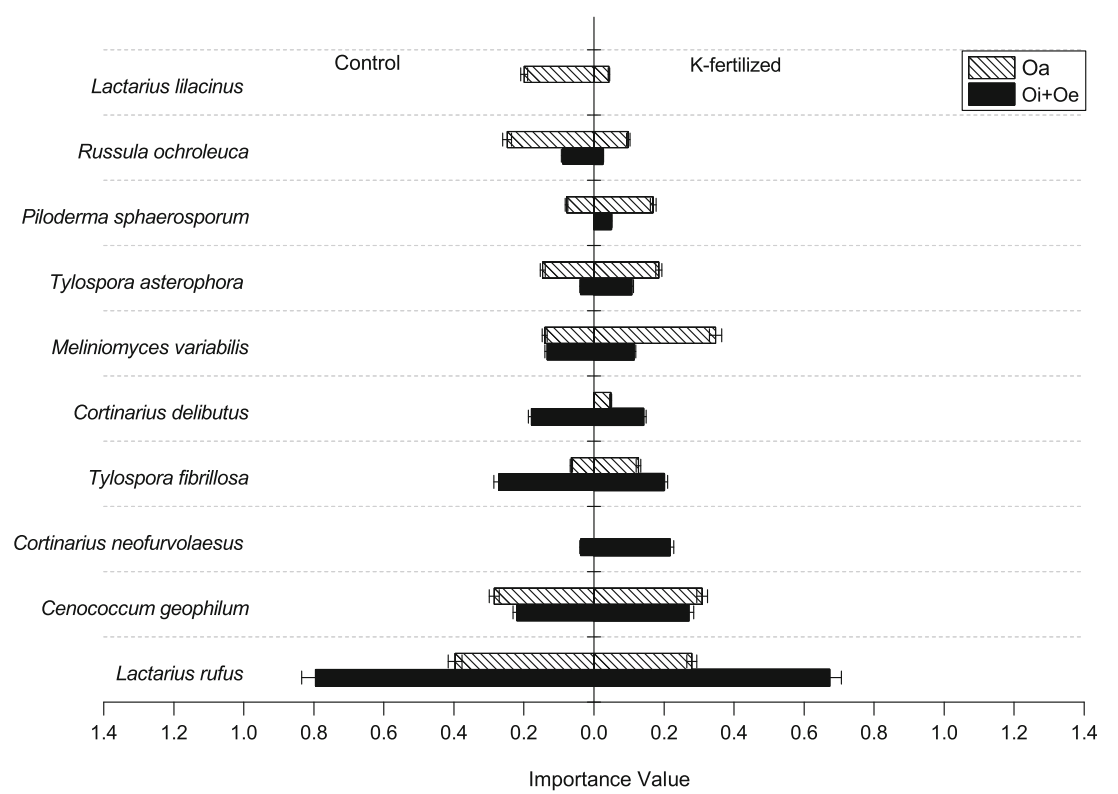

Fertilization with $\mathrm{MgSO}_{4}$ led to a rapid increase in the levels of $\mathrm{Mg}$ in fine roots and improved $\mathrm{Mg}$ nutrition. Magnesium deficiency is known to decrease $\mathrm{C}$ translocation to roots (Fink 1992). In many studies, elevated $\mathrm{CO}_{2}$ has also been shown to increase fine root biomass in deeper soil layers (Iversen 2010; Smith et al. 2013) and has been suggested to be the response to a greater $\mathrm{C}$ availability and a greater water and nutrient demand. However, the reason for the increase in root biomass in deeper soil layers is unknown (Iversen 2010).

In the mineral soil, the fine root biomass was ca. $47 \%$ higher after K-fertilization, and the fine root length in the mineral soil was ca. $48 \%$ greater after K-fertilization. The morphological traits of fine roots, such as root diameter and tissue density, are highly plastic in response to resource supply. This plasticity has been shown for both C (Smith et al. 2013) and soil conditions (Lõhmus et al. 1989). In other studies, addition of $\mathrm{N}$ and liming of soils was shown to reduce specific root length (Ostonen et al. 2007). Similarly, elevated $\mathrm{CO}_{2}$ was also shown to either reduce specific root length (Ostonen et al. 2007) or have no influence on root morphology (Smith et al. 2013). After K-fertilization, changes in specific root tip number and specific root length were again found only in the mineral soil, emphasizing the difference in the response of roots shown in the organic and mineral soil layers.

After K-fertilization, an increase in radial growth of the trees was determined suggesting an increase in $\mathrm{C}$ availability within the tree. In addition, $\mathrm{K}$ is known to be important in both phloem loading and unloading of sucrose (Hermans et al. 2006), and $\mathrm{K}$ deficiency is known to impede sucrose export from leaves resulting in a decrease in allocation to roots (Hermans et al. 2006). Thus, an increase in K-status with the tree has the potential to increase $\mathrm{C}$ allocation to roots. However, after K-fertilization, the basal area to fine root biomass did not change which suggests that there is no major change in allocation, but rather larger trees support a larger fine root system, and that this is formed preferentially in less exploited mineral soil layers. For example, for Picea abies, there is a strong positive correlation between stem cross sectional area and fine root biomass per tree (Finér et al. 2007). Thus, larger trees have a higher fine root biomass, and on a stand basis, fine root biomass will be higher without changes in allocation to fine roots.

\subsection{Distribution and diversity of mycorrhizas}

Potassium fertilization increased the radial growth of trees, and the proliferation of fine roots into the mineral soil, two effects that also occur under elevated $\mathrm{CO}_{2}$. The change in ectomycorrhizal community structure under high $\mathrm{CO}_{2}$ is often shown as a change in the abundance of dominant taxa (Fransson et al. 2001; Godbold et al. 2015) and has been related to changes in the supply of $\mathrm{C}$ to roots (Parrent and Vilgalys 2007). Recently, Clemmensen et al. (2015) showed that productivity of Picea abies was a factor most strongly related to changes in fungal community composition. In the control and $\mathrm{K}$-fertilized plots in total, 22 ectomycorrhizal taxa were determined, $65 \%$ of the estimated richness. Bruns (1995) suggested that 20-35 taxa typically occur in single species forests (Bruns 1995). In a young Picea abies plantation, Korkama et al. (2006) detected 34 ectomycorrhizal taxa, which was $75 \%$ of the estimated richness. In fast and slow growing clones of 11-year-old Picea abies, Korkama et al. (2006) showed that the faster growing clone had a more complex ectomycorrhizal community structure. Thirty taxa were detected in fast growing clones and 18 ectomycorrhizal taxa in slow growing clones (Korkama et al. 2006). The differences in 
the number of taxa were related to a higher fine root tip density in some of the fast growing clones. In the expanding root systems of the 11-year-old Picea abies, the higher fine root tips density probably results in a higher number of root tips for ectomycorrhizal colonization (Korkama et al. 2006). As in most studies of below ground ectomycorrhizal diversity, we have focused on the upper organic horizon, where root tip density is high (Rosling et al. 2003). After K-fertilization, faster growth has not affected the ectomycorrhizal community structure. The lack of change is also related possibly to a lack of change in the number of fine root tips in the upper soil layers, even if due to fine root turnover, there must have been a considerable renewal of fine roots during the 8 years after fertilization. In the study of Korkama et al. (2006), the relative abundance of Tylospora asteraphoa and Tylospora terrestis, the two most abundant taxa (total $55 \%$ ) on the slow growing clones, was negatively correlated with ectomycorrhizal taxa richness (Korkama et al. 2006). In the K-fertilization plots, T. fibrillosa had a lower abundance, and Tylospora asteraphoa had a higher abundance than on the control plots, but these two taxa only had a combine relative abundance of $15 \%$.

The most abundant taxa in this study, L. rufus and T. fibrillosa, occurred significantly more often in the $\mathrm{Oi}+\mathrm{Oe}$ layer compared to the Oa layer. As did both C. neofurvolaesus and $C$. delibutus, but for these two taxa, the differences were not significant. In contrast, the very abundant $C$. geophilum had no significant difference in occurrence in the $\mathrm{Oi}+\mathrm{Oe}$ and Oa layers. This distribution has been shown in a number of studies (Baier et al. 2006; Courty et al. 2008) where the medium distance exploration types (L. rufus, C. neofurvolaesus, and $C$. delibutus) occur more often in the loose substrate horizons $(\mathrm{Oi}+\mathrm{Oe})$ than the more compact Oa layers. However, the short distance exploration type T. fibrillosa was also found preferentially in the $\mathrm{Oi}+\mathrm{Oe}$ layer, suggesting that factors other than the compactness of the soil substrate may also be important, such as tolerance to fluctuations in soil temperature and moisture (Baier et al. 2006). Between the control and the $\mathrm{K}$-fertilization treatment, no differences in the relative abundance of exploration types or the hydrophobicity of the ectomycorrhizal taxa were shown.

Our study shows that fertilization of K-deficient stands of Picea abies results in an increase in radial growth, but that higher growth rates do not automatically result in a change in relative abundance and taxa richness of ectomycorrhizas. However, an increase in growth due to K-fertilization leads to great exploration of the mineral soil by fine roots.

\footnotetext{
Acknowledgments We thank Martin Wresowar, Frauke Neumann, and Marcel Hirsch for technical support. We thank two anonymous reviewers and the handling editor for helpful comments that have greatly improved the manuscript.
}

Compliance with ethical standards
Funding The work was initially supported by the BMLFUW grant GZ LE.3.2.3./0013-IV 2/2005 to KK and HS. We thank the Chinese Ministry of Education for support of LW and a Marie Curie grant GPF333996 LINKTOFUN to DG

\section{References}

Agerer R (1997) Colour atlas of ectomycorrhizae. Einhorn-Verlag Eduard Dietenberger GmbH, Germany

Baier R, Ingenhaag J, Blaschke H, Göttlein A, Agerer R (2006) Vertical distribution of an ectomycorrhizal community in upper soil horizons of a young Norway spruce (Picea abies [L.] Karst.) stand of the Bavarian Limestone Alps. Mycorrhiza 16:197-206. doi:10.1007/ s00572-006-0035-Z

Battie-Laclau P, Laclau JP, Beri C, Mietton L, Almeida Muniz MR, Cersózimo Arenque B, de Cassia PM, Jordan-Meille L, Bouillet JP, Nouvellon Y (2014) Photosynthetic and anatomical responses of Eucalyptus grandis leaves to potassium and sodium supply in a field experiment. Plant Cell Environ 37:70-81. doi:10.1111/pce. 12131

Bergh J, Linder S, Lundmark T, Elfving B (1999) The effect of water and nutrient availability on the productivity of Norway spruce in northern and southern Sweden. For Ecol Manage 119:51-62. doi:10. 1016/S0378-1127(98)00509-X

Bruns TD (1995) Thoughts on the processes that maintain local species diversity of ectomycorrhizal fungi. Plant and Soil 1:63-73. doi:10. 1007/bf02183055

Clemmensen KE, Finlay RD, Dahlberg A, Stenlid J, Wardle DA, Lindahl BD (2015) Carbon sequestration is related to mycorrhizal fungal community shifts during long-term succession in boreal forests. New Phytol 205:1525-1536. doi:10.1111/nph.13208

Courty PE, Franc A, Pierrat JC, Garbaye J (2008) Temporal changes in the ectomycorrhizal community in two soil horizons of a temperate oak forest. Appl Environ Microbiol 74:5792-5801. doi:10.1128/ AEM.01592-08

Cox F, Barsoum N, Lilleskov EA, Bidartondo MI (2010) Nitrogen availability is a primary determinant of conifer mycorrhizas across complex environmental gradients. Ecol Lett 13:1103-1113. doi:10.1111/ j.1461-0248.2010.01494.x

Douglas RB, Parker VT, Cullings KW (2005) Belowground ectomycorrhizal community structure of mature lodgepole pine and mixed conifer stands in Yellowstone National Park. For Ecol Manage 208:303-317. doi:10.1016/j.foreco.2004.12.011

Epron D, Laclau J-P, Almeida JC, Gonçalves JLM, Ponton S, Sette CR, Delgado-Rojas JS, Bouillet J-P, Nouvellon Y (2011) Do changes in carbon allocation account for the growth response to potassium and sodium applications in tropical Eucalyptus plantations? Tree Physiol 32:667-679. doi:10.1093/treephys/tpr107

Ericsson T, Kähr M (1993) Growth and nutrition of birch seedlings in relation to potassium supply rate. Trees 7:78-85. doi:10.1007/ BF00225473

Erland S, Taylor A (1999) Resupinate ectomycorrhizal fungal genera. In: Cairney JWG, Chambers SM (eds) Ectomycorrhizal fungi Key genera in profile. Springer, Berlin, Heidelberg, pp 347-363

Finér L, Helmisaari H, Lõhmus K, Majdi H, Brunner I, Børja I, Eldhuset T, Godbold D, Grebenc T, Konôpka B (2007) Variation in fine root biomass of three European tree species: Beech (Fagus sylvatica L.), Norway spruce (Picea abies L. Karst.), and Scots pine (Pinus sylvestris L.). Plant Biosyst 141:394-405. doi:10.1080/ 11263500701625897

Fink S (1992) Physiologische and strukturelle Veränderungen an Bäumen unter Magnesiummangel. Forstl Schriftenreihe 5:16-26 
Fransson P, Taylor AF, Finlay RD (2001) Elevated atmospheric $\mathrm{CO}_{2}$ alters root symbiont community structure in forest trees. New Phytol 152:431-442. doi:10.1046/j.0028-646X.2001.00276.x

Führer E, Neuhuber F (1998) Status diagnosis and rehabilitation concepts for the forest area Gleinalm. Forstliche Shriftenreihe 13:59-62

Glatzel G (1991) The impact of historic land use and modern forestry on nutrient relations of Central European forest ecosystems. Fertil Res 27:1-8. doi:10.1007/BF01048603

Godbold D, Vašutová M, Wilkinson A, Edwards-Jonášová M, Bambrick M, Smith AR, Pavelka M, Cudlin P (2015) Elevated atmospheric $\mathrm{CO}_{2}$ affects ectomycorrhizal species abundance and increases sporocarp production under field conditions. Forests 6:1256-1273. doi: $10.3390 /$ f6041256

Hahn G, Marschner H (1998) Effect of acid irrigation and liming on root growth of Norway spruce. Plant and Soil 199:11-22. doi:10.1023/ A: 1004254709452

Hay TN, Phillips LA, Nicholson BA, Jones MD (2015) Ectomycorrhizal community structure and function in interior spruce forests of British Columbia under long term fertilization. For Ecol Manage 350:8795. doi:10.1016/j.foreco.2015.04.023

Helmisaari HS, Hallbäcken L (1999) Fine-root biomass and necromass in limed and fertilized Norway spruce (Picea abies (L.) Karst.) stands. For Ecol Manage 119:99-110. doi:10.1016/S0378-1127(98)00514-3

Hermans C, Hammond JP, White PJ, Verbruggen N (2006) How do plants respond to nutrient shortage by biomass allocation? Trends Plant Sci 11:610-617. doi:10.1016/j.tplants.2006.10.007

Iversen CM (2010) Digging deeper: fine-root responses to rising atmospheric CO2 concentration in forested ecosystems. New Phytol 186: 346-357. doi:10.1111/j.1469-8137.2009.03122.x

Jonard M, Fürst A, Verstraeten A, Thimonier A, Timmermann V, Potočić N, Waldner P, Benham S, Hansen K, Merilä P (2014) Nutrient availability could constraint forest ecosystem response to global change in Europe. Global Change Research Symposium 2014-Human and Ecosystem Response to global Change, Evidence and Application. Ostuni, Brindisi, Italy., http://hdl.handle.net/2078.1/152055. Accessed 18 September 2014

Jones D, Rousk J, Edwards-Jones G, DeLuca T, Murphy D (2012) Biochar-mediated changes in soil quality and plant growth in a three year field trial. Soil Biol Biochem 45:113-124. doi:10.1016/j. soilbio.2011.10.012

Jones MD, Twieg BD, Ward V, Barker J, Durall DM, Simard SW (2010) Functional complementarity of Douglas-fir ectomycorrhizas for extracellular enzyme activity after wildfire or clearcut logging. Funct Ecol 24:1139-1151. doi:10.1111/j.1365-2435.2010.01699.x

Katzensteiner K, Schume H, Wresowar M, Spitzer H (2008) Effects of potassium nutrition upon drought stress disposition of Norway spruce. (Picea abies Karst.). Final report BMLFUW GZ LE.3.2.3./ 0013-IV 2/2005

Korkama T, Pakkanen A, Pennanen T (2006) Ectomycorrhizal community structure varies among Norway spruce (Picea abies) clones. New Phytol 171:815-824. doi:10.1111/j.1469-8137.2006.01786.x

Kreutzer K (1995) Effects of forest liming on soil processes. Plant and Soil 168:447-470. doi:10.1007/978-94-011-0455-5 51

Laclau JP, Almeida JC, Gonçalves JLM, Saint-André L, Ventura M, Ranger J, Moreira RM, Nouvellon Y (2009) Influence of nitrogen and potassium fertilization on leaf lifespan and allocation of aboveground growth in Eucalyptus plantations. Tree Physiol 29:111-124. doi:10.1093/treephys/tpn010

Lang C, Seven J, Polle A (2011) Host preferences and differential contributions of deciduous tree species shape mycorrhizal species richness in a mixed Central European forest. Mycorrhiza 21:297-308. doi: 10.1007/s00572-010-0338-y

Linder S, Troeng E (1980) Photosynthesis and transpiration of 20-yearold Scots pine. Ecological Bulletins 32:165-181

Lõhmus K, Oja T, Lasn R (1989) Specific root area: a soil characteristic. Plant and Soil 119:245-249. doi:10.1007/BF02370415
Marschner H, Dell B (1994) Nutrient uptake in mycorrhizal symbiosis. Plant and Soil 159:89-102. doi:10.1007/BF00000098

Mellert KH, Göttlein A (2012) Comparison of new foliar nutrient thresholds derived from van den Burg's literature compilation with established central European references. Eur J For Res 131:14611472. doi:10.1007/s10342-012-0615-8

Nadelhoffer KJ, Raich JW (1992) Fine root production estimates and belowground carbon allocation in forest ecosystems. Ecology 73: 1139-1147. doi: $10.2307 / 1940664$

Nohrstedt HÖ (2001) Response of coniferous forest ecosystems on mineral soils to nutrient additions: a review of Swedish experiences. Scand J For Res 16:555-573. doi:10.1080/02827580152699385

Norby RJ, DeLucia EH, Gielen B, Calfapietra C, Giardina CP, King JS, Ledford J, McCarthy HR, Moore DJ, Ceulemans R (2005) Forest response to elevated $\mathrm{CO}_{2}$ is conserved across a broad range of productivity. Proc Natl Acad Sci U S A 102:18052-18056. doi:10. 1073/pnas.0509478102

Norby RJ, Warren JM, Iversen CM, Medlyn BE, McMurtrie RE (2010) $\mathrm{CO}_{2}$ enhancement of forest productivity constrained by limited nitrogen availability. Proc Natl Acad Sci 107:19368-19373. doi:10. 1073/pnas. 1006463107

Ostonen I, Püttsepp Ü, Biel C, Alberton O, Bakker MR, Lõhmus K, Majdi H, Metcalfe D, Olsthoorn AF, Pronk A (2007) Specific root length as an indicator of environmental change. Plant Biosyst 141: 426-442. doi:10.1080/11263500701626069

Ouimet R, Moore J-D (2015) Effects of fertilization and liming on tree growth, vitality and nutrient status in boreal balsam fir stands. For Ecol Manage 345:39-49. doi:10.1016/j.foreco.2015.02.032

Parrent JL, Vilgalys R (2007) Biomass and compositional responses of ectomycorrhizal fungal hyphae to elevated $\mathrm{CO}_{2}$ and nitrogen fertilization. New Phytol 176:164-174. doi:10.1111/j.1469-8137.2007. 02155.x

Persson H, Ahlström K (1990) The effects of forest liming on fertilization on fine-root growth. Water Air Soil Pollut 54:365-375. doi:10.1007/ BF00298679

Pestana M, Santolamazza-Carbone S (2011) Defoliation negatively affects plant growth and the ectomycorrhizal community of Pinus pinaster in Spain. Oecologia 165:723-733. doi:10.1007/s00442010-1760-8

Peter M, Ayer F, Egli S (2001) Nitrogen addition in a Norway spruce stand altered macromycete sporocarp production and below-ground ectomycorrhizal species composition. New Phytol 149:311-325. doi:10.1046/j.1469-8137.2001.00030.x

Raspe S (1997) Fine-root development. In: Hüttl RF, Schaaf W (eds) Magnesium deficiency in forest ecosystems Kluwer. Springer, Dordrecht, pp 309-330

Read DJ, Leake JR, Perez-Moreno J (2004) Mycorrhizal fungi as drivers of ecosystem processes in heathland and boreal forest biomes. Can J Bot 82:1243-1263. doi:10.1139/B04-123

Rosling A, Landeweert R, Lindahl B, Larsson KH, Kuyper T, Taylor A, Finlay R (2003) Vertical distribution of ectomycorrhizal fungal taxa in a podzol soil profile. New Phytol 159:775-783. doi:10.1046/j. 1469-8137.2003.00829.x

Rygiewicz PT, Bledsoe CS (1984) Mycorrhizal effects on potassium fluxes by northwest coniferous seedlings. Plant Physiol 76:918923, doi: 10.1104/pp.76.4.918

Smith AR, Lukac M, Bambrick M, Miglietta F, Godbold DL (2013) Tree species diversity interacts with elevated $\mathrm{CO}_{2}$ to induce a greater root system response. Glob Chang Biol 19:217-228. doi:10.1111/gcb. 12039

Tamm CO (1991) Nitrogen in terrestrial ecosystems: questions of productivity, vegetational changes, and ecosystem stability. Springer Berlin Heidelberg, Germany

Tripler CE, Kaushal SS, Likens GE, Todd Walter M (2006) Patterns in potassium dynamics in forest ecosystems. Ecol Lett 9:451-466. doi: 10.1111/j.1461-0248.2006.00891.x 
Vanninen P, Mäkelä A (1999) Fine root biomass of Scots pine stands differing in age and soil fertility in southern Finland. Tree Physiol 19:823-830. doi:10.1093/treephys/19.12.823

Wurzburger N, Wright SJ (2015) Fine-root responses to fertilization reveal multiple nutrient limitation in a lowland tropical forest. Ecology 96:2137-2146. doi:10.1890/14-1362.1
Zanella A, Jabiol B, Ponge JF, Sartori G, De Waal R, Van Delft B, Graefe U, Cools N, Katzensteiner K, Hager H (2011) A European morphofunctional classification of humus forms. Geoderma 164:138-145. doi:10.1016/j.geoderma.2011.05.016 